\title{
Evidence of a Steroidogenic Enzyme Gene Dose Effect on Adrenal Gene Expression in Hereditary Rabbit Congenital Adrenal Hyperplasia
}

\author{
KOTARO IWAMOTO, XIMING YANG, FRASER M. ROGERSON, J. IAN MASON, JAMES \\ ARTWOHL, KRISTINE BOLIN, PAUL KLIMAH, PIETER SWART, AND SONGYA PANG \\ Department of Pediatrics and Biological Resources Laboratory, University of Illinois College of \\ Medicine, Chicago, Illinois 60612 [K.I., X.Y., J.A., K.B., P.K., S.P.]; Cecil H. and Ida Green \\ Center for Reproductive Biology Sciences, University of Texas, Southwestern Medical Center, \\ Dallas, Texas 75235 [F.M.R., J.I.M.]; and the Department of Biochemistry, University of \\ Stellenbosch, Stellenbosch, South Africa [P.S.]
}

\section{ABSTRACT}

We previously reported the gene deletion encoding cytochrome P-450 cholesterol side-chain cleavage enzyme (P$450_{\mathrm{SCC}}$, resulting in complete elimination of the adrenal gene expression and causing congenital adrenal hyperplasia in the rabbit. Using the rabbit congenital adrenal hyperplasia model, we investigated the wild type (wt) $\mathrm{P}-450_{\mathrm{scc}}$ gene dose effect on

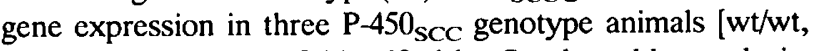
$\mathrm{wt} / \mathrm{mutant}(\mathrm{mt}), \mathrm{mt} / \mathrm{mt}$ ] identified by Southern blot analysis. Northern blots using a rabbit $\mathrm{P}-450_{\mathrm{SCC}} \mathrm{CDNA}$ probe revealed no detectable $\mathrm{P}-450_{\mathrm{SCC}} \mathrm{mRNA}$ in individual adrenals of animals with congenital adrenal hyperplasia $(\mathrm{mt} / \mathrm{mt})$ and approximately half or slightly less than half the levels of the mRNA in the pooled adrenals of five heterozygous (wt/mt) newborn animals compared with the mRNA levels in the pooled adrenals of five homozygous normal (wt/wt) newborn animals. Identical $\mathrm{P}-450_{\mathrm{SCC}} \mathrm{mRNA}$ levels were found individual adrenals of adult animals with regard to the P-450 ${ }_{\text {scc }}$ genotype, although at a higher expression level than in the newborn animals of the same genotype. Control Northern blots using human CPY21-B cDNA and cytoplasmic actin cDNA probes confirmed the accuracy and integrity of RNA. Western immunoblotting using antiovine $\mathrm{P}-450_{\mathrm{SCC}}$ antibody revealed decreased $\mathrm{P}-450_{\mathrm{SCC}}$ protein in the adrenals of $\mathrm{wt} / \mathrm{mt}$ animals at approximately half the level of the $\mathrm{P}-450_{\mathrm{SCC}}$ protein in the adrenals of the wt/wt animals. Baseline and ACTH-stimulated serum corticosterone (B) levels in vivo were similar between the age-matched $w t / m t$ and wt/wt animals, whereas ACTHstimulated $B$ levels in adult animals were higher than those in

CAH is a family of autosomal recessive disorders of adrenal steroidogenesis resulting from deficient activity

\footnotetext{
Received February 25, 1994; accepted June 28, 1994.

Correspondence and reprint requests: Songya Pang, M.D., Department of Pediatrics M/C 856, University of Illinois, 840 S. Wood St., Chicago, IL 60612.

Supported in part by USPHS Grant R01 HD24360 (to S.P.) and a biomedical research grant from the University of Illinois, School of Medicine at Chicago (to S.P.).

1 Presented at the Annual Meeting of the American Pediatric Society/Society for Research in Washington, DC, May 3-6, 1993.
}

the newborn animals irrespective of $\mathrm{P}-450_{\mathrm{SCC}}$ genotype. These data demonstrated for the first time the presence of a wt steroidogenic enzyme gene dose effect on gene expression in vivo at the levels of the mRNA and enzyme protein. With age, the gene dose-related gene expression was maintained, although at higher expression levels. The normal adrenal B-producing capacity in heterozygous, wt/mt animals despite the markedly decreased $\mathrm{P}-450_{\mathrm{sCC}}$ gene expression suggests the presence of either a mechanism compensating the availability of mitochondrial cholesterol substrate to overcome the decreased $\mathrm{P}-450_{\mathrm{SCC}}$ or rate-limiting effect of $\mathrm{P}-450_{\mathrm{SCC}}$ in the conversion of excess cholesterol substrate available in the adrenal mitochondria. The greater B-producing capacity under ACTH stimulation in the adult animals compared with the newborn animal irrespective of $\mathrm{P}-450_{\mathrm{scC}}$ genotype therefore is likely from the greater adrenal receptor capacity for $\mathrm{ACTH}$ rather than from the greater $\mathrm{P}-450_{\mathrm{ScC}}$ gene expression level. (Pediatr Res 36: 660-666, 1994)

\section{Abbreviations}

CAH, congenital adrenal hyperplasia

$\mathbf{P}_{-450}$ scc, P-450 cholesterol side-chain cleavage enzyme

21-OHase, 21-hydroxylase

wt, wild type

mt, mutant

HET, heterozygous

HOMO NORMAL, homozygous normal

B, corticosterone

of adrenal steroidogenic enzymes essential for glucocorticoid biosynthesis $(1,2)$. Inadequate glucocorticoid production in CAH causes increased ACTH secretion via the negative feedback mechanism from fetal life, resulting in adrenal cortical hyperplasia at birth (3). Investigation of the gene expression of affected steroidogenic enzyme in an animal model manifesting $\mathrm{CAH}$ may provide further understanding of molecular genetics of $\mathrm{CAH}$. We previ- 
ously reported an inherited lipoid $\mathrm{CAH}$ due to cytochrome $\mathrm{P}-450_{\mathrm{SCC}}$ deficiency in adrenal and gonadal steroidogenesis in a strain of rabbits $(4,5)$. The clinical, pathologic, and biochemical manifestations of $\mathrm{CAH}$ in the rabbit $(4,5)$ are nearly identical to the human lipoid $\mathrm{CAH}$ due to inability to convert cholesterol to steroid molecule in adrenal and gonadal steroidogenesis (6-10). We further defined that $\mathrm{P}-450_{\mathrm{SCC}}$ deficiency $\mathrm{CAH}$ in the rabbit is caused by a deletion mutation of the gene encoding $\mathrm{P}-450_{\mathrm{SCC}}$ completely eliminating $\mathrm{P}-450_{\mathrm{SCC}}$ gene expression in CAH adrenals (5).

To date in humans, the effect of wt steroidogenic enzyme gene dose on adrenal gene expression in vivo is limited to the findings of the presence or absence of hormonal abnormality to ACTH administration in HET normal subjects from families of patients with $\mathrm{CAH}$ disorders $(1,2,11-14)$. However, it is not known whether the presence or absence of the hormonal abnormality in vivo in the HET subjects results from or is associated with mildly, modestly, or significantly decreased steroidogenic enzyme mRNA and protein levels in the adrenals. In addition, various deleterious mutations of the gene encoding for steroidogenic enzyme in HET subjects for CAH disorders $(1,2,15)$ make the assessment of accurate wt gene dose effect on gene expression in adrenals and gonads difficult.

Thus, CAH in the rabbit is an excellent model of natural gene knockout for investigation of a steroidogenic enzyme gene dose effect on gene expression in adrenals and gonads $(4,5)$. Our previous work in the rabbit demonstrated two levels of adrenal P- $450_{\mathrm{SCC}}$ gene expression in phenotypically normal newborn animals and undetectable gene expression in CAH newborn animals $(4,5)$. We hypothesized that the variable $\mathrm{P}-450_{\mathrm{SCC}}$ gene expression in the rabbit is due to the effect of a single and double copy of the wt P-450 $0_{\text {SCC }}$ gene in the HET and HOMO NORMAL animals, respectively. We thus investigated $\mathrm{P}-450_{\text {SCC }}$ gene expression in adrenals of the three P- $450_{\text {SCC }}$ genotype animals identified by restriction fragment length polymorphism of the $\mathrm{P}-450_{\mathrm{SCC}}$ gene from families of $\mathrm{CAH}$ animals to determine the gene dose effect on the levels of P-450 $0_{\mathrm{SCC}}$ mRNA and enzyme protein. We further compared the P-450 $0_{\mathrm{SCC}}$ gene expression with adrenal steroid-producing capacity in vivo in the animals.

\section{METHODS}

Animals background and tissue collection. The animals with the CAH trait were derived by inbreeding and outcrossing known HET animals carrying the mt P-450 sCC $_{\text {S }}$ gene trait as described $(4,5)$. Animals with the $\mathrm{CAH}$ trait (inside strain) were killed at 12 to $24 \mathrm{~h}$ of life (newborn animals), and phenotypically normal adult animals were killed at age 9 mo. The age-matched control HOMO NORMAL newborn and normal adult New Zealand White rabbits (unrelated to the $\mathrm{CAH}$ pedigree) were purchased from an outside laboratory (outside strain). All animals were killed by a method approved by the Animal Care Committee of the University of Illinois. The CAH newborn animals were immediately identified by the presence of hyperplastic adrenals at autopsy. Tissues (adrenal, liver, and kidney) obtained from animals were immediately frozen in liquid nitrogen and stored at $-70^{\circ} \mathrm{C}$ until study. One of the adrenals from each animal was used for Northern blotting, and the other adrenal was used for Western immunoblotting in all animals. Body weight and adrenal weight of phenotypically normal newborn and adult animals were similar between the HET and HOMO NORMAL animals.

Southern blot analysis. Genomic DNA was extracted from the kidney or liver tissue from newborn animals and from leukocytes of blood samples obtained via venipuncture in adult rabbits using a lysis buffer and purified by phenol-chloroform and ethanol precipitation as described (5). For genotype identification, purified genomic DNA $(15 \mu \mathrm{g})$ was digested with $S s t \mathrm{I}$ and separated on a $0.7 \%$ agarose gel by electrophoresis. DNA fragments were transferred to a nylon membrane (Hybond-N Amersham, Arlington Heights, IL) and hybridized in a hybridization solution (Amersham) at $65^{\circ} \mathrm{C}$ for $3 \mathrm{~h}$ in the presence of ${ }^{32} \mathrm{P}$-labeled rabbit $\mathrm{P}-450_{\mathrm{SCC}}$ cDNA probe $(5)$. The final washing was carried out in $0.5 \times \operatorname{SSPE}(1 \times \mathrm{SSPE}=150$ $\mathrm{mM} \mathrm{NaCl}, 10 \mathrm{mM} \mathrm{NaH}{ }_{2} \mathrm{PO}_{4}$, and $1 \mathrm{mM}$ EDTA at $\mathrm{pH}$ 7.4), $0.1 \%$ SDS at $65^{\circ} \mathrm{C}$. The blot was then exposed to Kodak XAR film and autoradiographed for $18 \mathrm{~h}$ at $-70^{\circ} \mathrm{C}$.

Northern blot analysis. Total RNA was extracted from individual adrenals of adult and CAH newborn animals and from pooled adrenals $(n=5)$ of proven HET newborn animals and HOMO NORMAL newborn animals by restriction fragment length polymorphism analysis of the $\mathrm{P}-450_{\mathrm{SCC}}$ gene. RNA concentration was determined by the absorbance ratio at 260 and $280 \mathrm{~nm}$ as described (4, 5 ). The pooling of adrenals from HET and HOMO NORMAL newborn animals was necessary to obtain an adequate amount of RNA due to extremely small adrenals in the newborn (1-2 mg/gland). Total RNA was loaded on a $1.2 \%$ denaturing agarose gel containing $0.3 \mathrm{M}$ formaldehyde for electrophoresis, stained with ethidium bromide for visual examination of RNA amount equality, transferred to Hybond-N membrane, and hybridized in a hybridizing solution (Amersham) at $65^{\circ} \mathrm{C}$ for $3 \mathrm{~h}$ in the presence of ${ }^{32} \mathrm{P}$-labeled rabbit $\mathrm{P}-450_{\mathrm{SCC}}$ cDNA probe, human 21-OHase B cDNA probe, or human cytoplasmic actin cDNA probe. The final washing was carried out in $0.1 \times$ SSPE, $0.1 \%$ SDS at $65^{\circ} \mathrm{C}$. Autoradiography was performed as in Southern blot analysis. The relative amounts of $\mathrm{P}-450_{\mathrm{SCC}}, 21-\mathrm{OHase}$, and actin mRNA levels were determined by the band intensity in each autoradiogram and its comparison to the amount of RNA loaded, as well as by scanning densitometry of the autoradiogram of Northern blots of $\mathrm{P}-450_{\mathrm{scC}}, 21-\mathrm{OH}$ ase, and actin at various exposure periods.

Preparation of specific ${ }^{32}$ P-labeled cDNA probes. A cloned rabbit $\mathrm{P}-450_{\mathrm{SCC}}$ cDNA fragment was generated using polymerase chain reaction as described previously 
in the authors' laboratory (5). Human 21-OHase B cDNA probe was supplied by the American Type Culture Collection (Rockville, MD). Human cytoplasmic actin cDNA probe was provided by Dr. X. Yang at the University of Illinois, Chicago. These cDNA were labeled with ${ }^{32} \mathrm{P}$ by random priming technique using $\mathrm{dCTP}$, the kit reagents, and protocol supplied by Amersham. The probes were further purified by passing them through a spin column (Bio-Rad, Richmond, CA).

Western blot analysis. Protein was extracted from the pooled adrenals of five HET or five HOMO NORMAL newborn animals and individual adrenals of CAH newborn animals and all adult animals. The adrenal tissue was homogenized in lysing solution, then the protein concentration was determined by a BCA protein determination kit (Sigma Chemical Co., St. Louis, MO). Each adrenal homogenate was resolved by one-dimensional electrophoresis on a $7.5 \%$ polyacrylamide gel containing $0.1 \%$ SDS at $4^{\circ} \mathrm{C}$ and $12 \mathrm{~mA}$ for $18 \mathrm{~h}$. The separated proteins were transferred from the gel to a nitrocellulose filter (Bio-Rad) or an Immobillon-P PVDF filter (Millipore, Bedford, MA) at $4^{\circ} \mathrm{C}$ and $100 \mathrm{~V}$ for $1 \mathrm{~h}$. The filter was preincubated with buffer A [10 mM Tris- $\mathrm{HCl}(\mathrm{pH}$ 7.4), $150 \mathrm{mM} \mathrm{NaCl}, 0.2 \% \mathrm{NP}-40]$ for $30 \mathrm{~min}$ at room temperature, then incubated for $2 \mathrm{~h}$ at room temperature with buffer $\mathrm{A}$ containing antipolyclonal ovine P-450 $\mathrm{SCC}$ antiserum specific for cytochrome $\mathrm{P}-450_{\mathrm{SCC}}$ in several species, including rabbit $(4,16)$. The filter was washed for 30 min with buffer $A$ and then incubated for $1 \mathrm{~h}$ at room temperature with ${ }^{125} \mathrm{I}$ protein A (Amersham) at a concentration of $0.33 \mu \mathrm{Ci} / \mathrm{mL}$ in buffer A. After washing with PBS for $30 \mathrm{~min}$, the protein antibody complexes were visualized by autoradiography. The relative amount of $\mathrm{P}-450_{\text {SCC }}$ was assessed by both the band intensity of the autoradiogram and the radioactivity of the band detected by an AMBIS radioanalyzer (Bioscan, Inc., Washington, DC).

In vivo adrenal steroid-producing capacity test. Synthetic ACTH 1-24 (Cortrosyn $6 \mu \mathrm{g} / \mathrm{kg}$, Organon, West Orange, $\mathrm{NJ}$ ) was administered by intramuscular injection to HET adult animals $(n=9)$ and HOMO NORMAL adult animals $(n=5)$ as well as young ( 2 mo old) HET animals $(n$ $=2$ ) and HOMO NORMAL animals $(n=2)$. Blood samples were obtained before and $30 \mathrm{~min}$ after ACTH injection. Adrenal steroid-producing capacity was assessed by the levels of serum baseline and ACTHstimulated corticosterone by an RIA as described previously (4).

\section{RESULTS}

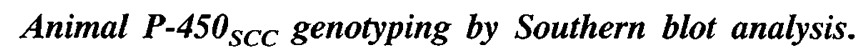
An example of genotypes of animals determined by DNA analysis is shown in Figure 1. Genomic DNA from a family of an affected offspring revealed two alleles of the $\mathrm{P}-450_{\text {ScC }}$ gene: one allele revealed a $5.5-\mathrm{kb}$ Sst I restriction fragment and the other allele revealed $4.0-\mathrm{kb}$ and $1.5-\mathrm{kb} S s t \mathrm{I}$ restriction fragments. The HET father dem-
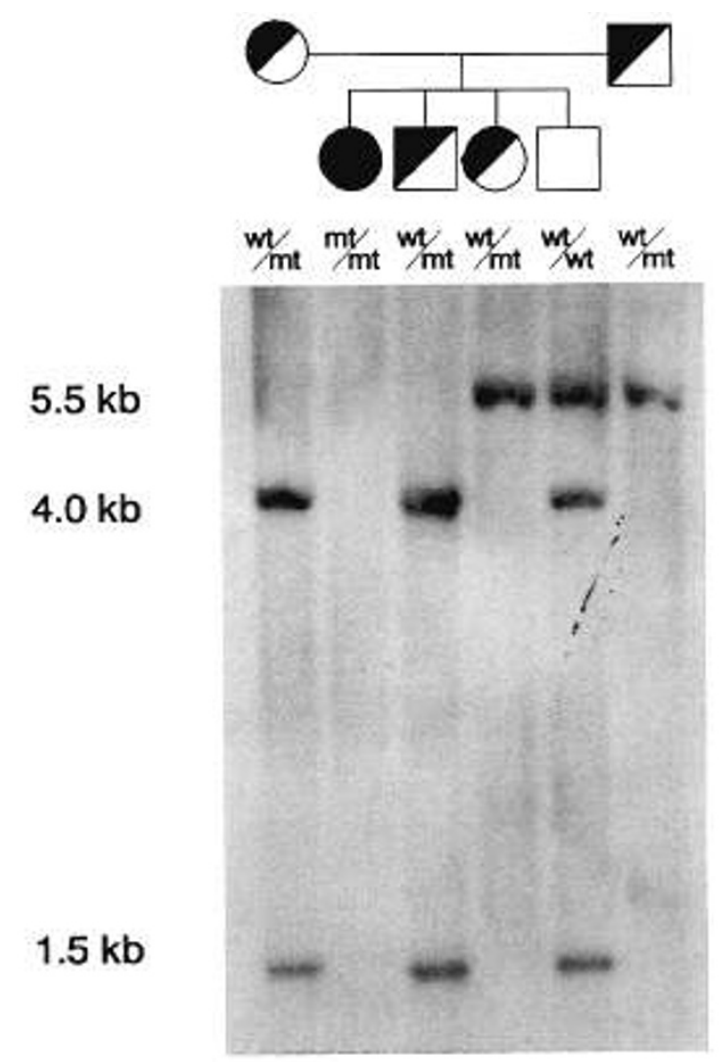

Figure 1. Southern blot analysis of the rabbit P-450 $\mathrm{SCC}$ genomic DNA digested with SstI. The HET (wt/mt) mother animal carries a wt $\mathrm{P}_{-450} \mathrm{SCC}$ allele of 4.0 - and $1.5-\mathrm{kb}$ Sst I fragments. The HET (wt/mt) father animal carries the other wt allele of a $5.0-\mathrm{kb}$ Sst I fragment. The $\mathrm{CAH}$ offspring $(\mathrm{mt} / \mathrm{mt})$ has HOMO deletion of both wt $\mathrm{P}-450_{\mathrm{SCC}}$ alleles. The genotype of phenotypically normal offspring was identified as wt/mt (HET) when one wt P-450 $\mathrm{Scc}$ allele was present and wt/wt (HOMO NORMAL) when both wt P-450 ${ }_{\mathrm{SCC}}$ alleles were present.

onstrated the presence of a $5.5-\mathrm{kb}$ Sst I allele and the absence of $4.0-\mathrm{kb}$ and $1.5-\mathrm{kb}$ alleles for the P-450 $\mathrm{SCC}$ gene. The HET mother revealed the presence of $4.0-\mathrm{kb}$ and $1.5-\mathrm{kb}$ alleles only and the absence of a $5.5-\mathrm{kb}$ Sst I allele. The genomic DNA from a CAH newborn offspring showed the absence of both $\mathrm{P}-450_{\mathrm{SCC}}$ Sst $\mathrm{I}$ alleles, indicating deletion of the P-450 $\mathrm{SCC}$ gene. The genotypes of the phenotypically normal newborn sibling rabbits were identified as HET when only one allele P-450 SCC $_{\text {Sst }}$ fragment was detected and as HOMO NORMAL when both P- $450_{\mathrm{SCC}}$ allele fragments were detected by Southern blotting.

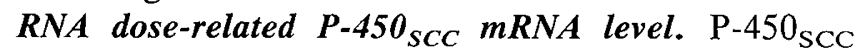
mRNA levels at 4,2 , and $1 \mu \mathrm{g}$ of adrenal RNA from pooled adrenals of control HOMO NORMAL newborn animals (of outside strain) revealed an RNA dose-related $\mathrm{P}-450_{\mathrm{SCC}}$ mRNA level based on the band intensity (Fig. $2 A$ ). The densitometry scanning revealed nearly identical ratios of P-450 $0_{\mathrm{SCC}}$ to $21-\mathrm{OH}$ ase mRNA levels in 1-, 2-, and $4-\mu \mathrm{g}$ lanes of HOMO NORMAL newborn adrenals (Table 1). The band intensities of P-450 $0_{\mathrm{SCC}}$ mRNA in $4-\mu \mathrm{g}$ and $2-\mu \mathrm{g}$ RNA lanes of the HOMO NORMAL newborn adrenals were greater than and similar to, respectively, the band intensity of 4- $\mu$ g RNA lanes from 
A

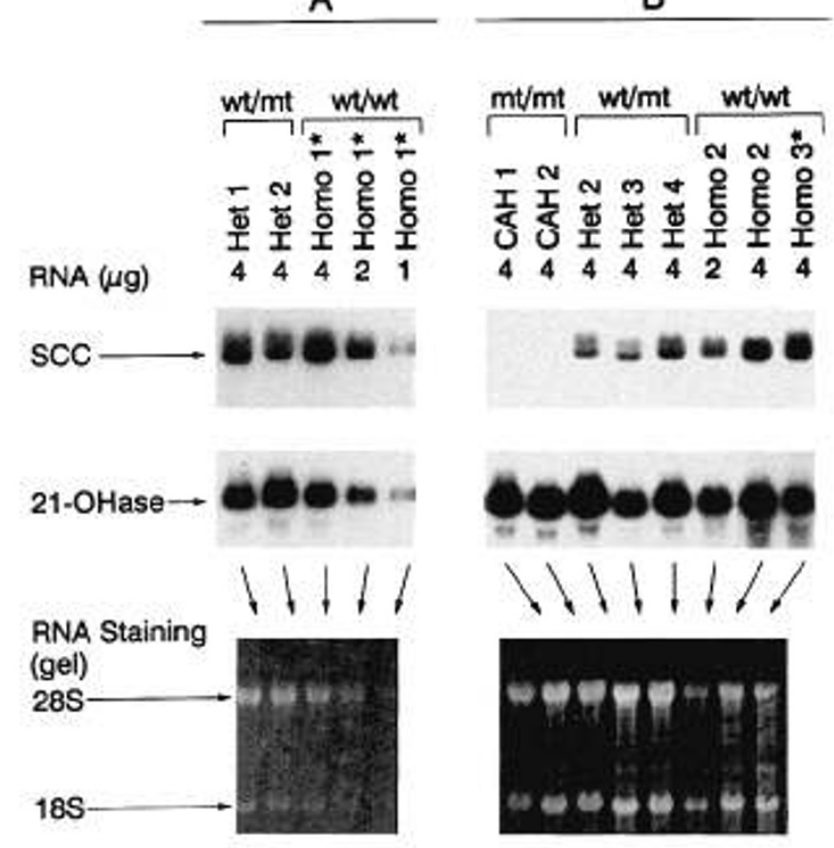

Figure 2. $A$, RNA dose-related $\mathrm{P}-450_{\mathrm{SCC}}$ (SCC) mRNA levels based on the band intensity of the autoradiogram in the HOMO NORMAL $($ Homo $=\mathrm{wt} / \mathrm{wt})$ newborn animals and its comparison with the mRNA levels in the HET $($ Het $=\mathrm{wt} / \mathrm{mt})$ newborn animals. Each lane represents RNA from pooled adrenals of five animals of the same genotypes. 21-OHase mRNA levels represent the control blot study. The number above Het or Homo indicates group identification of pooled adrenals of animals of the same genotype. An asterisk indicates outside-strain animals. $B$, Comparison of $\mathrm{P}-450_{\mathrm{SCC}}$ (SCC) gene expression (mRNA levels) in the three $\mathrm{P}-450_{\mathrm{scc}}$ genotypes of newborn animals. 21-OHase mRNA represents the control blot study.

two groups of HET newborn adrenals (Fig. 2A). The band intensity of the control blot study using human 21-B cDNA probe demonstrated the RNA dose-related $(4,2$, and $1 \mu \mathrm{g}$ ) 21-OHase mRNA levels of the control HOMO NORMAL newborn adrenals and similar 21-OHase mRNA levels between the 4- $\mu$ g RNA of the HET and HOMO NORMAL newborn adrenals.

$P-450_{\text {SCC }}$ gene dose effect on adrenal gene expression in newborn animals of the three $P-450_{\text {SCC }}$ genotypes. $\mathrm{P}-450_{\mathrm{SCC}}$ $\mathrm{mRNA}$ levels in adrenals of CAH animals ( $\mathrm{mt} / \mathrm{mt}$ alleles),
HET animals (wt/mt alleles), and HOMO NORMAL animals (wt/wt alleles) of the inside and outside strains were compared by band intensity in relation to the amount of RNA loaded (Fig. $2 B$ ). P-450 scC $_{\text {mRNA was }}$ not detected in two CAH adrenals. P-450 $0_{\mathrm{SCC}} \mathrm{mRNA}$ levels in adrenals of three groups of HET newborn animals at a 4- $\mu \mathrm{g}$ RNA dose were similar to those of HOMO NORMAL newborn adrenals of the inside strain at a 2- $\mu \mathrm{g}$ RNA dose and were markedly decreased compared with those of HOMO NORMAL newborn adrenals of either the inside- or outside-strain animals at a 4- $\mu \mathrm{g}$ RNA dose. P-450 ${ }_{\text {SCC }}$ mRNA levels were similar between the inside strain and outside strain of HOMO NORMAL animals. These data indicate the presence of a wt P- $450_{\text {SCC }}$ gene dose effect at the mRNA level in vivo. 21-OHase mRNA levels determined by the band intensity were detected in CAH adrenals and were also similarly expressed in the HET or HOMO NORMAL adrenals, except for somewhat low expression in one 4- $\mu$ g RNA lane of HET adrenals and one 2- $\mu \mathrm{g}$ RNA lane of HOMO NORMAL adrenals. RNA staining in the latter two lanes revealed the presence of $4 \mu \mathrm{g}$ of RNA in the lane of the HET adrenals and an unequivocally low degree of staining in the 2- $\mu \mathrm{g}$ RNA lane in the HOMO NORMAL adrenals. The densitometry scanning of the lanes of HET adrenals revealed one-half ratios of $\mathrm{P}-450_{\mathrm{SCC}}$ to $21-\mathrm{OH}$ ase mRNA levels and P-450 SCC $_{\text {to }}$ actin mRNA levels of the HOMO NORMAL adrenals, whereas the ratios of 21-OHase to actin mRNA levels were similar between the HET and HOMO NORMAL adrenals (Table 1).

$P-450_{S C C}$ gene expression in adult HET (wt/mt) and HOMO NORMAL (wt/wt) animals. The mRNA levels were determined by the band intensity in relation to the amount of RNA loaded (Fig. 3). P-450 scC $_{\text {mRNA levels }}$ at a 4- $\mu \mathrm{g}$ RNA dose from three HET adult adrenals for the P-450 SCC $\mathrm{mt}$ gene were similar to or slightly lower than the mRNA levels at a 2- $\mu \mathrm{g}$ RNA dose from adrenals of three HOMO NORMAL adult animals of either the inside or outside strain. Control 21-OHase and actin mRNA levels at a 4- $\mu$ g RNA dose in HET and HOMO NORMAL adrenals were similar. 21-OHase and actin

Table 1. Adrenal $m R N A$ quatification by densitometry scanning on Northern blot analysis in three genotypes of $P-450_{S C C}$ in newborn animals and two genotypes of $P-450_{S C C}$ in adult animals

\begin{tabular}{|c|c|c|c|c|c|c|c|c|}
\hline & \multicolumn{5}{|c|}{ Newborn animals } & \multicolumn{3}{|c|}{ Adult animals } \\
\hline & \multicolumn{3}{|c|}{ wt/wt } & \multirow{2}{*}{$\begin{array}{l}\mathrm{wt} / \mathrm{mt} \\
(4 \mu \mathrm{g}) \\
\end{array}$} & \multirow{2}{*}{$\begin{array}{l}\mathrm{mt} / \mathrm{mt} \\
(4 \mu \mathrm{g})\end{array}$} & \multicolumn{2}{|c|}{ wt/wt } & \multirow{2}{*}{$\begin{array}{l}\mathrm{wt} / \mathrm{mt} \\
(4 \mu \mathrm{g})\end{array}$} \\
\hline & $1 \mu \mathrm{g}$ & $2 \mu \mathrm{g}$ & $4 \mu \mathrm{g}$ & & & $2 \mu g$ & $4 \mu \mathrm{g}$ & \\
\hline mRNA: $\mathrm{P}-450_{\mathrm{scd}} / 21-\mathrm{OHase}$ & $1.0^{*}$ & $0.8^{*}$ & $1.02 \pm 0.06 \dagger$ & $0.48 \pm 0.07 \dagger$ & $\begin{array}{l}0^{*} \\
0^{*}\end{array}$ & $0.82 \pm 0.04 \dagger$ & $1.14 \pm 0.08 \dagger$ & $0.53 \pm 0.09 \dagger$ \\
\hline$n$ & 1 & 1 & 5 & 7 & 2 & 3 & 5 & 5 \\
\hline mRNA: $\mathrm{P}-450_{\mathrm{scd}}$ actin & & $1.0^{*}$ & $\begin{array}{l}1.1^{*} \\
1.3^{*}\end{array}$ & $0.51 \pm 0.06 \dagger$ & $\begin{array}{l}0^{*} \\
0^{*}\end{array}$ & $0.97 \pm 0.03 \dagger$ & $1.65 \pm 0.17 \dagger$ & $0.87 \pm 0.07 \dagger$ \\
\hline$n$ & & 1 & 2 & 3 & 2 & 3 & 5 & 5 \\
\hline mRNA: 21-OHase/actin & & $1.33^{*}$ & $\begin{array}{l}1.45^{*} \\
1.27^{*}\end{array}$ & $1.13 \pm 0.38 \dagger$ & $\begin{array}{l}1.25^{*} \\
1.33^{*}\end{array}$ & $1.16 \pm 0.01 \dagger$ & $1.62 \pm 0.09 \dagger$ & $2.16 \pm 0.09 \dagger$ \\
\hline$n$ & & 1 & 2 & 3 & 2 & 3 & 5 & 5 \\
\hline
\end{tabular}

\footnotetext{
* Individual values.
}

$\dagger$ Mean \pm SEM. 

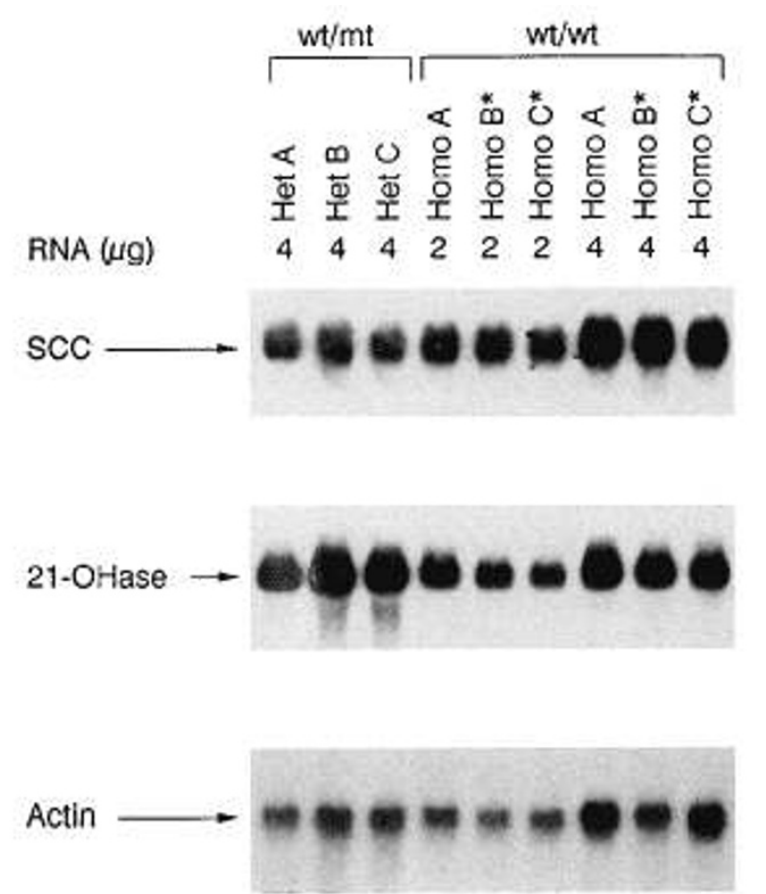

Figure 3. $\mathrm{P}-450_{\mathrm{SCC}}(\mathrm{Scc}) \mathrm{mRNA}$ level based on the band intensity of the autoradiogram in adult animals. Het, HET (wt/mt) animals; Homo, HOMO NORMAL (wt/wt) animals. The letters $A, B$, and $C$ above Het or Homo indicate the individual animal's identification. An asterisk indicates outside-strain animals. 21-OHase mRNA and actin mRNA levels represent the control blot studies.

mRNA levels at a 2- $\mu \mathrm{g}$ RNA dose of HOMO NORMAL adrenals were approximately 50\% lower than the mRNA levels at a 4- $\mu \mathrm{g}$ RNA dose of both HET and HOMO NORMAL adrenals. P-450 5 SCC mRNA levels were similar in the adrenals of HOMO NORMAL animals of inside and outside strains. These data indicate the presence of the same effect of wt P-450 ${ }_{\mathrm{SCC}}$ gene dose at the level of $\mathrm{P}-450_{\text {SCC }}$ mRNA in adrenals of adult animals in vivo as in the newborn animals. The densitometry scanning of lanes of adult HET adrenals revealed approximately one-half ratios of $\mathrm{P}-450_{\mathrm{SCC}}$ to $21-\mathrm{OH}$ ase $\mathrm{mRNA}$ and $\mathrm{P}-450_{\mathrm{SCC}}$ to actin mRNA levels of HOMO NORMAL adrenals, whereas the ratios of 21-OHase to actin mRNA levels did not differ significantly between the HET and HOMO NORMAL adrenals (Table 1).

Comparison of adrenal $P-450_{\text {SCC }}$ gene expression between newborn and adult animals with regard to the $P-450_{S C C}$ genotype. P- $450_{\mathrm{SCC}} \mathrm{mRNA}$ levels in adrenals of adult animals were greater than those in newborn animals of the same P-450 ${ }_{\text {SCC }}$ genotype by the band intensity (Fig. 4). This finding was verified by several other Northern blot analyses (not shown). P-450 scC $_{\text {mRNA levels in }}$ adrenals of the HET animals (wt/mt) were lower than the mRNA levels in the age-matched HOMO NORMAL animals (wt/wt), as shown in Figures 2 and 3 and Table 1. 21-OHase mRNA levels assessed by the band intensity were similarly detected in adrenals of both newborn and adult animals irrespective of age.

$P-450_{S C C}$ protein level in adrenals from the three $P-450_{S C C}$ genotypes of newborn animals and from the two genotypes of
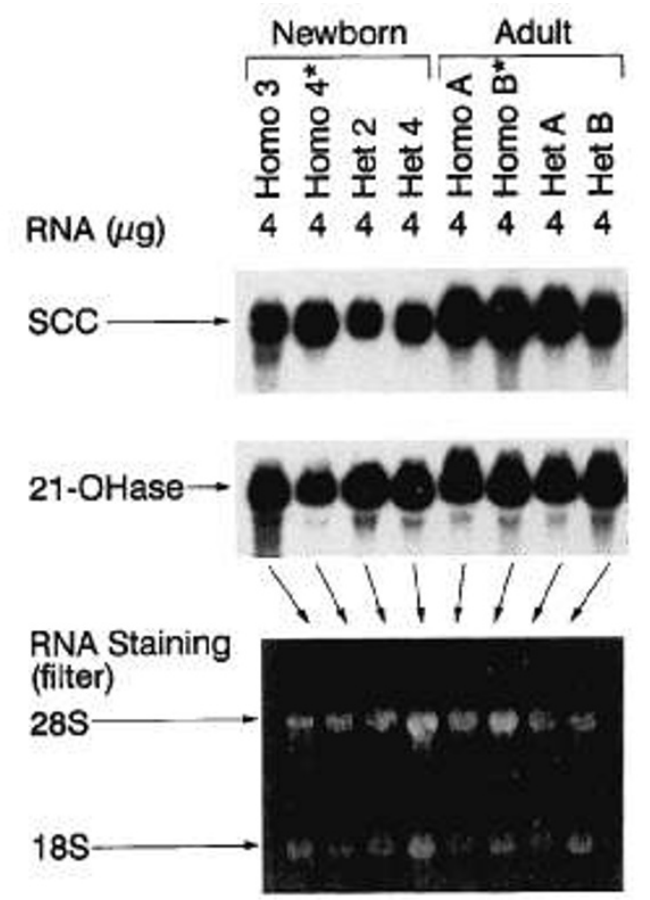

Figure 4. Comparison of $\mathrm{P}-450_{\mathrm{SCC}}(S C C)$ mRNA level based on the band intensity of the autoradiogram between newborn and adult animals of the same genotypes. Het, HET animals; Homo, HOMO NORMAL animals. The number above Het or Homo indicates group identification of newborn animals whose adrenals were pooled. The letter above Het or Homo indicates identification of adult individual animals. An asterisk indicates outside-strain animals.

adult animals. Based on the band intensity of newborn animals (Fig. $5 A$ ), $\mathrm{P}-450_{\mathrm{scc}}$ protein was not detected in adrenals of two CAH animals. P- $450_{\mathrm{SCC}}$ protein levels by the band intensity in $100 \mu \mathrm{g}$ of adrenal protein from the three groups of HET newborn animals were slightly and markedly lower than the levels in the $50 \mu \mathrm{g}$ and $100 \mu \mathrm{g}$ of adrenal protein, respectively, from the two groups of HOMO NORMAL animals. In adult animals (Fig. $5 B$ ), $\mathrm{P}-450_{\mathrm{SCC}}$ protein levels (by the band intensity) in $100 \mu \mathrm{g}$ of adrenal protein in three HET animals appeared to be lower than the level found in $100 \mu \mathrm{g}$ of adrenal protein of three HOMO NORMAL animals and were similar to or slightly lower than the level found in $50 \mu \mathrm{g}$ of adrenal protein in the same HOMO NORMAL animals. The ${ }^{125} \mathrm{I}$ radioactivity of the $\mathrm{P}-450_{\mathrm{SCC}}$ band detected by an AMBIS radioanalyzer revealed $1432-1457$ net counts in the $100-\mu \mathrm{g}$ protein bands of all HET animals, $1660-1693$ net counts in the $50-\mu \mathrm{g}$ protein bands of HOMO NORMAL adrenals, and 2504-3019 net counts in the 100- $\mu$ g protein bands from the HOMO NORMAL animals. Radioactivity in the lanes of $\mathrm{CAH}$ animals were not different from the background.

In vivo serum. Baseline serum $B$ levels in nine adult HET animals $(1.24 \pm 0.52 \mu \mathrm{g} / \mathrm{dL})$ were similar to the $B$ levels in five adult HOMO NORMAL animals (1.52 \pm $1.03 \mu \mathrm{g} / \mathrm{dL}$ ). ACTH-stimulated B levels rose similarly in both genotypes of animals (HET, $21.0 \pm 8.0 \mu \mathrm{g} / \mathrm{dL}$; HOMO NORMAL, $19.9 \pm 7.9 \mu \mathrm{g} / \mathrm{dL}$ ). In two young HET animals, baseline and ACTH-stimulated B levels 

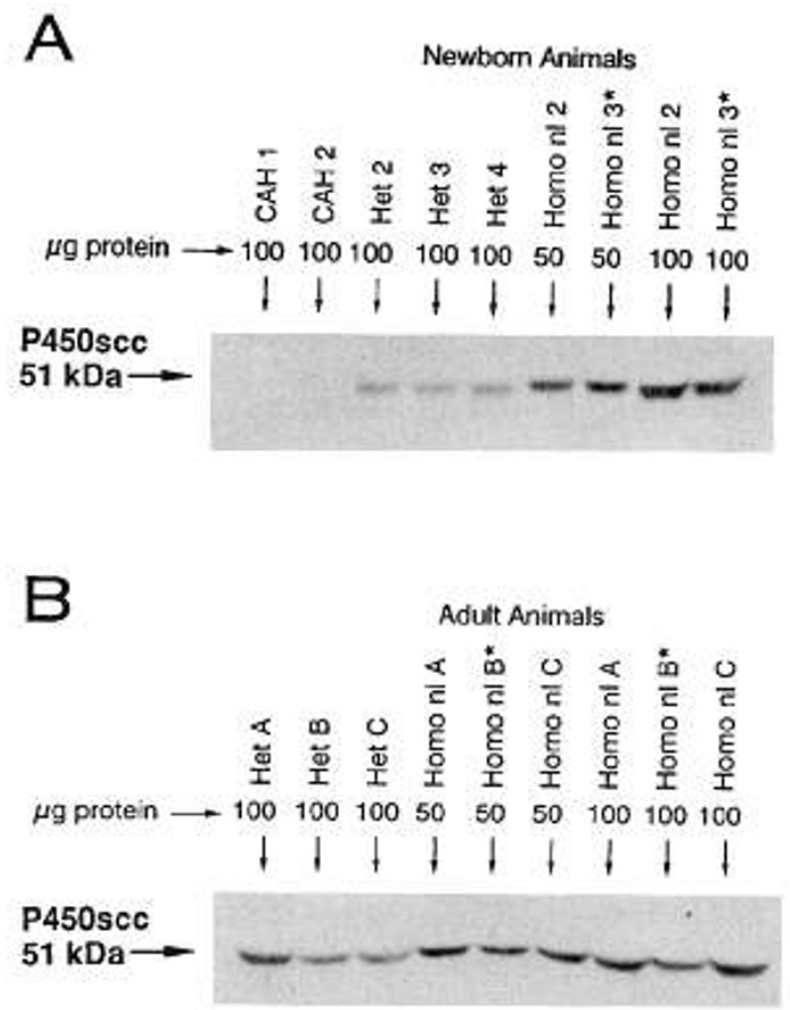

Figure 5. $A, \mathrm{P}-450_{\mathrm{scc}}$ protein levels in the three $\mathrm{P}-450_{\mathrm{scC}}$ genotypes of newborn animals. Het, pooled adrenals $(n=5)$ of five HET newborn animals; Homo $n l$, pooled adrenals $(n=5)$ of five HOMO NORMAL newborn animals. The number above Het or Homo nl indicates identification of the pooled adrenals. An asterisk indicates outside-strain animals. $B, \mathrm{P}-450_{\mathrm{scC}}$ protein levels in the Het and Homo $\mathrm{nl}$ adult animals. The letter above Het or Homo nl indicates identification of the individual adrenal of the animal. An asterisk indicates outside-strain animals.

were 1.48 and $1.44 \mu \mathrm{g} / \mathrm{dL}$ and 7.51 and $8.35 \mu \mathrm{g} / \mathrm{dL}$, respectively. In two young HOMO NORMAL animals, the baseline B levels $(2.19$ and $1.15 \mu \mathrm{g} / \mathrm{dL})$ and ACTHstimulated B levels $(8.39$ and $6.68 \mu \mathrm{g} / \mathrm{dL})$ were similar to those in the young HET animals. These hormonal data indicate that adrenal steroid-producing capacity in vivo is similar in HET and HOMO NORMAL animals.

\section{DISCUSSION}

It is now well known that human CAH disorders result from various deleterious mutations of each specific gene encoding the adrenals or gonadal steroidogenic enzyme $(1,2,15)$. Various deleterious mutations of the gene would likely affect gene expression to various degrees. Thus, investigation of the wt gene dose effect on adrenal gene expression based on in vivo hormonal response in the human HET subjects may not accurately reflect the effect of wt gene dose on the gene expression. Moreover, an ACTH stimulation test in vivo in proven human HET subjects for CAH disorders demonstrated both the presence and absence of mildly decreased enzyme activity in the heterozygous state (11-14). In 21-OHase deficiency, mildly increased ACTH-stimulated precursor hormone (17-hydroxyprogesterone) levels in proven HET subjects suggested the presence of decreased gene function on the enzyme activity $(11,12)$. In $11 \beta$-hydroxylase deficiency

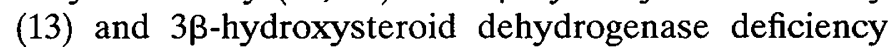
(14), the proven HET subjects exhibited no adrenal hormonal abnormality under ACTH stimulation. Furthermore, it is not known whether the mildly decreased 21-OHase activity in HET subjects proven for 21-OHase

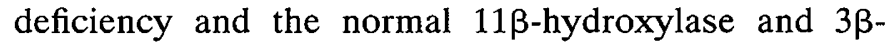
hydroxysteroid dehydrogenase activities in the HET subjects for enzyme deficiency result from the same or slightly or markedly decreased adrenal steroidogenic enzyme mRNA and protein levels. Thus, investigation into the functional relationship of single and double doses of steroidogenic enzyme gene from the gene expression (mRNA and protein level) to gene product level (hormonal secretion) will further aid in understanding of the molecular genetics of $\mathrm{CAH}$.

Investigation of the $\mathrm{P}-450_{\mathrm{SCC}}$ gene expression in adrenals of the three $\mathrm{P}-450_{\mathrm{SCC}}$ genotypes of animals demonstrated unequivocally the presence of the wt P-450 $\mathrm{SCC}$ gene dose effect on the adrenal mRNA and protein levels but not at the hormonal product level. P- $450_{\text {SCC }}$ mRNA in adrenals was consistently absent in $\mathrm{CAH}$ animals and decreased in the HET animals at approximately half the level of the mRNA in the HOMO NORMAL animals. The levels of the P-450 $0_{\text {SCC }}$ mRNA were similar among animals of the same genotype and were also nearly identical between the HOMO NORMAL animals of the inside and outside strains. This gene dose-related gene expression was present in both newborn and adult animals, although at higher levels of expression in adult animals than in newborn animals of the same genotype. These data confirm the presence of a P- $450_{\mathrm{SCC}}$ gene dose effect on adrenal P-450 scc $_{\text {gene expression at the mRNA level }}$ and suggest increasing $\mathrm{P}-450_{\mathrm{ScC}}$ gene expression with age. The findings of the steroidogenic enzyme gene doserelated expression at the mRNA level in the rabbit are similar to the heterozygous expression in mice carrying the photoreceptor-specific rd allele, $\mathrm{H}$ beta 58 allele, or Snap gene allele (17-19). The $\mathrm{P}-450_{\text {scC }}$ protein level in adrenals was not detected in $\mathrm{CAH}$ animals and was decreased in the HET animals at approximately one half of the enzyme protein detected in the HOMO NORMAL animals. This indicates that there is a parallel relationship in the mRNA levels and the enzyme protein levels. This further confirmed the presence of $\mathrm{P}-450_{\mathrm{SCC}}$ gene dose effect at the level of gene product, the enzyme protein. $\mathrm{P}-450_{\mathrm{SCC}}$ gene expression is steroidogenic tissue specific $(16,20-25)$. Recent reports suggest that $\mathrm{P}-450_{\mathrm{SCC}}$ activity in human and bovine adrenal and bovine and rat gonadal cells may be dependent on the overall amount of enzyme present and changes in the level of P-450 ${ }_{\mathrm{SCC}}$ mRNA (16, $21-23,26)$. Thus, if $\mathrm{P}-450_{\mathrm{scc}}$ mRNA levels are decreased, it would likely result in decreased $\mathrm{P}-450_{\mathrm{SCC}}$ protein and decreased activity.

However, despite markedly decreased adrenal $\mathrm{P}-450_{\mathrm{SCC}}$ mRNA and protein levels in the HET animals, nearly identical baseline and ACTH-stimulated serum B 
levels in the HET animals compared with the HOMO NORMAL animals indicate the presence of normal adrenal steroidogenic function in the HET animals and the presence of similar P-450 $0_{\mathrm{SCC}}$ activity in HET and HOMO NORMAL animals. $\mathrm{P}-450_{\mathrm{SCC}}$ is a rate-limiting enzyme in the biosynthetic pathway; the amount of cholesterol available for cleavage determines the level of B synthesis and secretion, and the transfer of cholesterol substrate across the mitochondrial membrane is regulated at a number of steps $(15,27-29)$. Thus, similar adrenal steroid-producing capacity despite the low $\mathrm{P}-450_{\mathrm{SCC}}$ gene expression in HET animals and the twice greater level of $\mathrm{P}-450_{\text {SCC }}$ gene expression in HOMO normal animals in vivo may result from the rate-limiting effect of $\mathrm{P}-450_{\mathrm{SCC}}$ in converting the possibly excess cholesterol substrate available in the mitochondria. Alternatively, a compensatory mechanism(s) may be available for provision of adequate cholesterol substrate across the mitochondrial membrane to maintain normal steroidogenic function in the presence of low P-450 $\mathrm{SCC}$ in the HET animals. In addition, the greater B-producing capacity under ACTH stimulation by the adult adrenals than in newborn adrenals irrespective of the P-450 ${ }_{\mathrm{SCC}}$ genotype appears to result from the larger adrenal receptor capacity for ACTH rather than the higher $\mathrm{P}-450_{\mathrm{SCC}}$ gene expression level in adult animals. The findings of $\mathrm{P}-450_{\mathrm{SCC}}$ gene expression in the three genotypes of animals suggest that in human HET $\mathrm{CAH}$ subjects a compensatory mechanism exists to maintain adequate adrenal steroidogenic function in the presence of low levels of the steroidogenic enzyme mRNA and enzyme protein levels in the adrenals.

$\mathrm{CAH}$ disorders in humans often result from the compound HET mutation of the gene encoding the enzyme $(12,15)$. Thus, evaluation of gene dose effect on gene expression in family members of patients with $\mathrm{CAH}$ resulting from compound HET mutations may not provide the linear relationship of gene dose function in the gene expression. The rabbit model of P-450 $0_{\text {SCC }}$ deficiency $\mathrm{CAH}$ due to $\mathrm{P}-450_{\mathrm{SCC}}$ gene deletion resulting in identical manifestation of human lipoid $\mathrm{CAH}$ allowed examination of molecular genetics of the compound HOMO affected state, HET normal state, and HOMO NORMAL state of a steroidogenic enzyme gene at the levels of mRNA, enzyme protein, and hormonal production. In conclusion, this study using the natural gene knockout model of $\mathrm{CAH}$ in the rabbit demonstrates for the first time the presence of a wt P-450 $0_{\text {SCC }}$ enzyme gene dose effect on gene expression in vivo at the levels of the mRNA and enzyme protein. The possible mechanism by which normal adrenal cortical function is maintained in the HET animals despite markedly decreased $\mathrm{P}-450_{\mathrm{SCC}}$ gene expression is speculated.

\section{REFERENCES}

1. Miller WL, Levine LS 1987 Molecular and clinical advances in congenital adrenal hyperplasia. J Pediatr 111:1-17

2. Pang S 1993 Congenital adrenal hyperplasia. In: Current Review of Pediatric Endocrinology. Serono Symposia, Washington, DC, pp 101-102
3. Potter EL, Craig JM 1975 Pathology of the Fetus and Infant, 3rd Ed. Yearbook Medical Publishers, Chicago

4. Pang S, Yang X, Wang M, Tissot R, Nino M, Manaligod J, Bullock LP, Mason JI 1992 Inherited congenital adrenal hyperplasia in the rabbit: absent cholesterol side-chain cleavage cytochrome P450 gene expression. Endocrinology 131:181-186

5. Yang X, Iwamoto K, Wang M, Artwohl J, Mason JI, Pans S 1993 Inherited congenital adrenal hyperplasia in the rabbit is caused by a deletion in the gene encoding cytochrome P450 cholesterol side-chain cleavage enzyme. Endocrinology 132:1977-1982

6. Prader A, Gurtner HP 1955 Das Syndrom des Pseudohermaphroditismus masculinus bei kongenitaler Nebennierenrinden-Hyperplasie ohne Androgenuberproduktion. Helv Paediatr Acta 10:397-412

7. Degenhart HJ, Visser KHA, Boon H, O'Doherty NJ 1972 Evidence for deficient $21 \alpha$-cholesterol-hydroxylase activity in adrenal tissue of a patient with lipoid adrenal hyperplasia. Acta Endocrinol (Copenh) 71:512-518

8. O’Doherty NJ 1964 Lipoid adrenal hyperplasia. Guys Hosp Rep 113:368-379

9. Koizumi S, Kyoya S, Miyawaki T, Kidani $H$, Funabashi $T$, Nakashima $H$, Nakanuma Y, Ohta G, Itagaki E, Kattagiri M 1977 Cholesterol side-chain cleavage enzyme activity and cytochrome P450 content in adrenal mitochondria of a patient with congenital lipoid adrenal hyperplasia (Prader disease). Clin Chim Acta 77:301-306

10. Hauffa B, Miller WL, Grumbach MM, Conte A, Kaplan SL 1985 Congenital adrenal hyperplasia due to deficient cholesterol side-chain cleavage activity $(20,22$-desmolase) in a patient treated for 18 years. Clin Endocrinol 23:481-493

11. Childs B, Grumbach MM, Van Wyk JJ 1956 Virilizing adrenal hyperplasia: a genetic and hormonal study. J Clin Invest 35:213-222

12. Lorenzen F, Pang S, New MI, Dupont B, Pollack M, Chow DM, Levine LS 1979 Hormonal phenotype and HLA-genotype in families of patients with congenital adrenal hyperplasia (21-hydroxylase deficiency). Pediatr Res 13:1356-1360

13. Pang S, Levine LS, Lorenzen F, Chow D, Pollack M, Dupont B, Genel M, New MI 1980 Hormonal studies in obligate heterozygotes and siblings of patients with $11 \beta$-hydroxylase deficiency congenital adrenal hyperplasia. J Clin Endo Metab 50:586-589

14. Chang YT, Zhang L, Mason I, Murry B, Wang J, Keming L, Garibaldi L, Bourdney C, Pang S 1994 Redefining hormonal criteria for mild $3 \beta$-hydroxysteroid dehydrogenase ( $3 \beta$-HSD) deficiency (def) congenital adrenal hyperplasia (CAH) by molecular analysis of the type II 3ß-HSD gene. Pediatr Res 35:96A(abstr)

15. Miller WL 1988 Molecular biology of steroid hormone synthesis. Endocr Rev 9:295-318

16. John ME, Simpson ER, Carr BR, Magness RR, Rosenfeld CR, Waterman MR, Mason JI 1987 Ontogeny of adrenal steroid hydroxylases: evidence for cAMP-independent gene expression. Mol Cell Endocrinol 50:263-268

17. Viczian A, Sanyal S, Toffenetti J, Chader GJ, Farber DB 1992 Photoreceptorspecific mRNAs in mice carrying different allelic combinations at the rd and rds loci. Exp Eye Res 54:853-860

18. Lee JJ, Radice G, Perkins CP, Costantini F 1992 Identification and characterization of a novel, evolutionarily conserved gene disrupted by the murine $\mathrm{H}$ beta 58 embryonic lethal transgene insertion. Development 115:277-288

19. Hess EJ, Jinnah HA, Kozak CA, Wilson MC 1992 Spontaneous locomotor hyperactivity in a mouse mutant with a deletion including the Snap gene on chromosome 2. J Neurosci 12:2865-2874

20. Chung B, Matteson KJ, Voutilainen R, Mohandas TK, Miller WL 1986 Human cholesterol side-chain cleavage enzyme, P450scc: cDNA cloning, assignment of the gene to chromosome 15, and expression in the placenta. Proc Natl Acad Sci USA 83:8962-8966

21. McMasters KM, Dickson LA, Shamy RV, Robischon K, Macdonald GL, Moyle WR 1987 Rat cholesterol side-chain cleavage enzyme (P-450scc): use of a cDNA probe to study the hormonal regulation of P-450scc mRNA levels in ovarian granulosa cells. Gene 57:1-9

22. John ME, Simpson ER, Waterman MR, Mason JI 1986 Regulation of cholesterol side-chain cleavage cytochrome P-450 gene expression in adrenal cells in monolayer culture. Mol Cell Endocrinol 45:197-204

23. Voutilainen R, Tapanainen J, Chung B, Matteson KJ, Miller WL 1986 Hormonal regulation of P450scc (20,22-desmolase) and P450c17 $(17 \alpha-$ hydroxylase/17,20-lyase) in cultured human granulosa cells. J Clin Endocrinol Metab 63:202-207

24. Doody KJ, Lorence MC, Mason JI, Simpson ER 1990 Expression of messenger ribonucleic acid species encoding steroidogenic enzymes in human follicles and corpora lutea throughout the menstrual cycle. J Clin Endocrinol Metab 70:1041-1045

25. Hedin L, Rodgers RJ, Simpson ER, Richards JS 1987 Changes in content of cytochrome P45017 $\alpha$, cytochrome P450scc, and 3-hydroxy-3-methylglutaryl $\mathrm{CoA}$ reductase in developing rat ovarian follicles and corpora lutea: correlation with theca cell steroidogenesis. Biol Reprod 37:211-223

26. John ME, John MC, Ashley P, MacDonald RJ, Simpson ER, Waterman MR 1984 Identification and characterization of cDNA clones specific for cholesterol side-chain cleavage cytochrome P-450. Proc Natl Acad Sci USA 81:5628-5632

27. Hanukoglu I 1992 Steroidogenic enzymes: structure, function and role in regulation of steroid hormone biosynthesis. J Steroid Biochem Mol Biol 43:799_804

28. Simpson ER, Waterman MR 1992 Regulation of expression of adrenocorticol enzymes. In: James VHT (ed) The Adrenal Gland. Raven Press, New York, pp 191-207

29. Mason JI, Arthur JR, Boyd GS 1987 Regulation of cholesterol metabolism in rat adrenal tissue. Mol Cell Endocrinol 10:209-223 